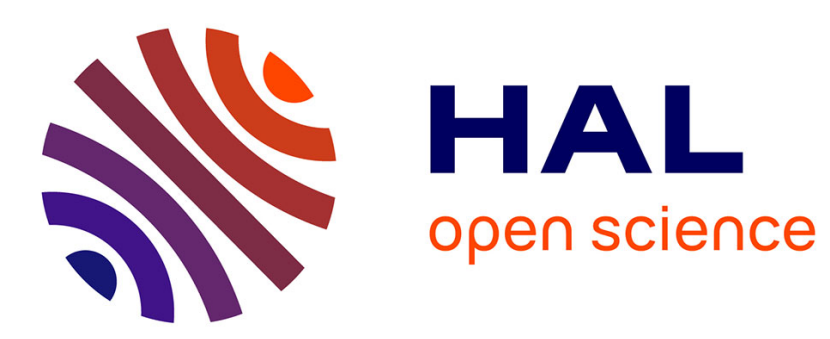

\title{
Is there a stratospheric fountain?
}

Jean-Pierre Pommereau, G. Held

\section{To cite this version:}

Jean-Pierre Pommereau, G. Held. Is there a stratospheric fountain?. Atmospheric Chemistry and Physics Discussions, 2007, 7 (3), pp.8933-8950. hal-00328208

\section{HAL Id: hal-00328208 \\ https://hal.science/hal-00328208}

Submitted on 25 Jun 2007

HAL is a multi-disciplinary open access archive for the deposit and dissemination of scientific research documents, whether they are published or not. The documents may come from teaching and research institutions in France or abroad, or from public or private research centers.
L'archive ouverte pluridisciplinaire HAL, est destinée au dépôt et à la diffusion de documents scientifiques de niveau recherche, publiés ou non, émanant des établissements d'enseignement et de recherche français ou étrangers, des laboratoires publics ou privés. 
Atmos. Chem. Phys. Discuss., 7, 8933-8950, 2007 www.atmos-chem-phys-discuss.net/7/8933/2007/

(C) Author(s) 2007. This work is licensed under a Creative Commons License.

Is there a

stratospheric

fountain?

J.-P. Pommereau and

G. Held

\section{Is there a stratospheric fountain?}

\section{J.-P. Pommereau ${ }^{1}$ and G. Held ${ }^{2}$}

${ }^{1}$ Service d'Aéronomie, CNRS, Verrières le Buisson, France

${ }^{2}$ Instituto de Pesquisas Meteorológicas, UNESP, Bauru, Brazil

Received: 1 June 2007 - Accepted: 12 June 2007 - Published: 25 June 2007

Correspondence to: J.-P. Pommereau (pommereau @aerov.jussieu.fr)

Title Page

Abstract

Introduction

Conclusions

References

Tables

Figures

14

I

4

Back

Close

\section{Full Screen / Esc}

Printer-friendly Version

Interactive Discussion 


\section{Abstract}

The impact of convection on the thermal structure of the Tropical Tropopause Layer (TTL) was investigated from a series of four daily radiosonde ascents and weather S-band radar observations carried out during the HIBISCUS campaign in the South

5 Atlantic Convergence Zone in Southeast Brazil in February 2004. The temperature profiles display a large impact of convective activity on the thermal structure of the TTL. Compared to non-active periods, convection is observed to result in a cooling of $4.5^{\circ} \mathrm{C}$ to $7.5^{\circ} \mathrm{C}$ at the Lapse Rate Tropopause at $16 \mathrm{~km}$, propagating up to $19 \mathrm{~km}$ or $440 \mathrm{~K}$ potential temperature levels in the stratosphere in most intense convective cases.

10 Consistent with the diurnal cycle of echo top heights seen by a S-band weather radar, a systematic temperature diurnal cycle is observed in the layer, displaying a rapid cooling of $3.5^{\circ} \mathrm{C}$ on average $\left(-9^{\circ},-2^{\circ} \mathrm{C}\right.$ extremes) during the development phase of convection in the early afternoon during the most active period. Since the cooling occurs during daytime within a timescale of 6-h, its maximum amplitude is at the altitude of the Cold

15 Point Tropopause at $390 \mathrm{~K}$ and temperature fluctuations associated to gravity waves do not display significant diurnal change, the afternoon cooling of the TTL cannot be attributed to radiation, advection, gravity waves or adiabatic lofting. It implies a fast insertion of adiabatically cooled air parcels by overshooting turrets followed by mixing with the warmer environment. During most intense convective days, the overshoot is shown to penetrate the stratosphere up to $450 \mathrm{~K}$ potential temperature level. Such fast updraft offers an explanation for the presence of ice crystals, and enhanced water vapour layers observed up to $18-19 \mathrm{~km}(410-430 \mathrm{~K})$ in the same area by the HIBISCUS balloons and the TROCCINOX Geophysica aircraft, as well as high tropospheric chemical species concentrations in the TTL over land observed from space.

25 Overall, injection of cold air by irreversible mixing of convective overshoots as proposed by Danielsen (1982) do not appear as episodic isolated features, but common and systematic events over a land convective area, that is a Stratospheric Fountain. Though the two-stages process proposed by Sherwood (2000) may also be operative,

Is there a

stratospheric fountain?

J.-P. Pommereau and G. Held

Title Page

Abstract

Conclusions

Tables

Figures

14

4

Back

Introduction

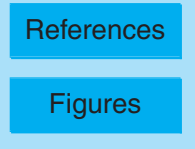

$>1$

$\checkmark$

Close
Full Screen / Esc

Printer-friendly Version

Interactive Discussion 
it offers a mechanism for producing the chemical, moisture and thermal properties observed in the stratosphere. The consistency between convective cooling of the TTL and weather radar echoes heights observed during the summer over South-East Brazil and the TRMM radar OPFs and LIS lightning events maximum frequencies, the latter

5 showing also maximum events over Africa, South-East Asia, the Indonesian Islands and Northern Australia depending on the season (Liu and Zipser, 2005), suggests the existence of several "Stratospheric Fountains" over continents instead of the oceanic area of Micronesia as proposed by Newell and Gould-Stewart (1982), which appears a region of little overshoot.

\section{Introduction}

The tropical tropopause is the source region of all trace gas species controlling stratospheric ozone chemistry and climate, further transported at global scale by the BrewerDobson circulation. It is also the region of dehydration process resulting in the drying of air entering the stratosphere. However, the potential impact of chemically ac15 tive short-lived species, or aerosols of different nature, and the dehydration process, are highly dependent on the timescale at which troposphere-to-stratosphere transport (TST) takes place, which is still not clearly established.

Based on the recognition of the temperature of the tropopause colder than anywhere else, the hypothesis was made by Newell and Gould-Stewart (1981) of the existence 20 of preferential area of TST, the "Stratospheric Fountain" over Micronesia, also called the maritime continent. However, the hypothesis was never demonstrated. Although unambiguous cases of convective stratosphere penetration have been occasionally reported, they were never seen over oceanic areas but continental regions, e.g. by Danielsen $(1982,1993)$ over Australia. However, several studies (e.g. Highwood and 25 Hoskins, 1998; Folkins et al., 1999) suggest that such overshooting in the TTL is not common and thus probably unimportant at global scale. An alternative mechanism was thus proposed (Holton and Gettleman 2001) of a two steps process of fast convective

Is there a

stratospheric fountain?

J.-P. Pommereau and G. Held

Title Page

Abstract

Conclusions

Tables

Figures

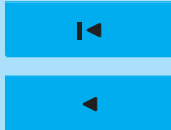

$\triangleleft$

Back

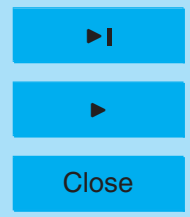

Full Screen / Esc

Printer-friendly Version

Interactive Discussion 
lofting up to the base of the TTL, around $14 \mathrm{~km}$, followed by a large scale slow diabatic ascent following the radiative heating of air parcels (Gettelman et al., 2002; Corti et al., 2005), possibly enhanced by additional radiative heating from cirrus clouds (Hartmann et al., 2001; Corti et al., 2006). The suggestion was then made by Sherwood 5 (2000) of a "mixing layer" of convective overshooting deep into the TTL instead of at the bottom only, followed by irreversible mixing, detrainment, and subsequent slow ascent in the lower stratosphere. This suggestion was recently supported by cloud resolving model (CRM) simulations showing that convection also influences the heat balance in the TTL and therefore may not be ignored Kuang and Bretherton (2004). Moreover, 10 from inspection of wind data above the maritime continent, it has been shown by Sherwood (2000) that the time-averaged mass flux near the tropopause over the maritime continent would be in fact downward, prompting the concept of "Stratospheric Drain" instead. The difficulty with this concept is that it would require an unidentified energy sink which the author proposed to be irreversible injection of cold heavy air at great heights by overshooting clouds somewhere else.

However, likely because of the lower outgoing long-wave radiation (OLR) indicating higher cloud-tops over the maritime continent and the difficulty of making measurements inside or above intense land convective systems, most of observations were carried out over oceanic areas where the picture could be quite different from land convective regions. Indeed, as shown by Alcala and Dessler (2002) from comparisons between thermal imagery and radar measurements from the orbit aboard Tropical Rainfall Measurement Mission (RMM), OLR is not a good indicator of cloud-top altitude and thus of overshooting across the tropopause. In contrast to what it is generally accepted, the radar indicates higher and more frequent "overshooting precipitation features" (OPF) above land areas of Africa, South America and large islands of Indonesia (Liu and Zipser, 2005). The radar observations are very consistent with the maximum frequency of lightning flashes seen by the Lightning Imaging Sensor (LIS) also aboard TRMM, indicative of fast updraft velocity in the upper troposphere. Furthermore, land convection displays a marked diurnal cycle with a maximum development

\section{Is there a \\ stratospheric fountain? \\ J.-P. Pommereau and G. Held}

Title Page
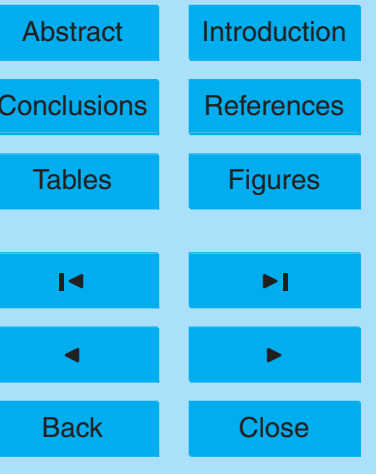

Full Screen / Esc

Printer-friendly Version

Interactive Discussion 
around 16:00 LT, in contrast to the small diurnal change over oceans (Yang and Slingo, 2001; Nowicki and Merchant 2004, Liu and Zipser, 2005). The still pending question is thus to know the altitude reached by the detrainment and irreversible mixing of tropospheric air in the TTL or the lower stratosphere above intense convection developing 5 in the afternoon over land.

Here we investigate the impact of land convection on the thermal structure and composition of the TTL from a series of radiosonde ascents and S-band weather radar observations in one of the most intense convective region, the South Atlantic Convergence Zone (SACZ) in Southeast Brazil during the summer of 2004. The experiment

10 is part of a HIBISCUS European project carried in cooperation with the Brazilian Meteorological Research Institute (IPMet) of the São Paulo State University (UNESP) (Pommereau et al., 2007).

\section{Thermal change associated to convection}

The observational data are those of 105 Vaisala RS80 radiosonde (RS) ascents car15 ried out between 24 January and 11 March from Bauru at $22^{\circ} \mathrm{S}, 49^{\circ} \mathrm{W}$ in Brazil. On 19 days between 31 January and 20 February the RS were released at a frequency of four times a day at 00:00, 06:00, 12:00, 18:00 UT that is 21:00, 03:00, 09:00, 15:00 local time (LT). Figure 1 displays the temperature deviation in reference to a campaign mean profile. Alternative periods of tropospheric warming and cooling of up to $\pm 5^{\circ} \mathrm{C}$ amplitude can be observed associated to the slow forth and back motion of the South Atlantic Convergence Zone (SACZ) over the station. Black lines are showing the variation of altitude of the $340 \mathrm{~K}$ and $370 \mathrm{~K}$ potential temperature levels, whose difference varying from $4 \mathrm{~km}$ to $8 \mathrm{~km}$ is an indicator of convection intensity. Most active systems were present from 3-9 February followed by a period of lesser convection from 10-13

25 February, when the SACZ moved a few hundred kilometres to the N-E. It was followed by a relatively long period between 14-26 February of medium convection when the SACZ gradually moved back over the State of São Paulo, but the most active region

Is there a

stratospheric fountain?

J.-P. Pommereau and G. Held

Title Page

Abstract

Conclusions

Tables

Figures

14

4

Back

Introduction

References

-

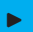

Close
Full Screen / Esc

Printer-friendly Version

Interactive Discussion 
remained about 200-300 km west of Bauru. Then followed a new period of calm between 28 February and 3 March and convection again on 5-8 March. However, the radiosonde sampling was not homogenous during the whole campaign. The series of four daily ascents covers 5 days during the most active period from 5-9 Feb (later ref5 erenced as High Convection), 4 days of calm from 10-13 Feb (called Low Convection) followed by 8 days from 14-21 Feb of intermediate activity (called later Medium Convection). Figure 2 displays the mean temperature profiles and the lapse rate during the three periods, and the difference between high, medium convection and low convective profiles. All profiles exhibit a lapse rate tropopause (LRT, dT/dZ $\leq \pm 2^{\circ} \mathrm{C} / \mathrm{km}$ following 10 WMO definition) around $16 \mathrm{~km}(370 \mathrm{~K})$ surmounted by a cold point tropopause (CPT) $1.5-2 \mathrm{~km}$ higher. Remarkably, the CPT is the highest $\left(18 \mathrm{~km},-73.5^{\circ} \mathrm{C}, 415 \mathrm{~K}\right)$ in the absence of convection, supporting the idea suggested by Thuburn and Craig (2002) and Gettelman et al. (2002), that the CPT could be a stratospheric feature of radiative origin, which can exist independently of convection. However, convection has indeed 15 a strong impact on the CPT temperature and altitude. But as already noted by Seidel et al. (2001) and Sherwood et al. (2003), if increased convection results in a cooling by up to $7^{\circ} \mathrm{C}$, it lowers the CPT and not the opposite. The temperature difference between convective and low-convective periods in the right panel of Fig. 2 exhibits a warming of the troposphere by $4-6^{\circ} \mathrm{C}$ between $5 \mathrm{~km}$ and $13 \mathrm{~km}$, followed by a cooling above the equilibrium level at $13-13.5 \mathrm{~km}$, reaching a maximum of $4.5-7.5^{\circ} \mathrm{C}$ at the altitude of the LRT around $370 \mathrm{~K}$. The cooling extends to $400 \mathrm{~K}$ in medium convective activity, and $460 \mathrm{~K}$ in the most intense cases. If adiabatic lofting only was involved, this would correspond to a maximum vertical displacement of $600 \mathrm{~m}(350 \mathrm{~m})$ at the LRT in high (medium) convection, reducing to $500 \mathrm{~m}(100 \mathrm{~m})$ at $18 \mathrm{~km}$ and $200 \mathrm{~m}(0 \mathrm{~m})$ at $20 \mathrm{~km})$.

25 The amplitude of the cooling of the TTL associated with land convection over the SACZ in the summer is significantly larger and extends to altitude levels higher than the $2-3^{\circ} \mathrm{C}$ at $100 \mathrm{hPa}$ reported by Kim and Dessler (2004) from temperature profiles measured by the Atmospheric Infrared Sounder (AIRS) onboard the AQUA satellite, but over oceans only because of retrieval limitations. However, it is of the same magni-

Is there a

stratospheric fountain?

J.-P. Pommereau and G. Held

Title Page

Abstract

Conclusions

Tables

Figures

14

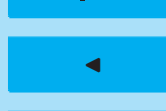

$>1$

Back

Close

Full Screen / Esc

Printer-friendly Version

Interactive Discussion 
tude of the $6-10^{\circ} \mathrm{C}$ cooling around $18 \mathrm{~km}$ reported by Johnson and Kriete (1982) over convective events in the South China sea offshore Borneo Island during the monsoon season, or the $10^{\circ} \mathrm{C}$ reported by Danielsen (1993) over a continental-maritime systems over Australia during the ER-2 STEP campaign in 1987.

5 Overall, the thermal impact of convection on the TTL appears more intense over land than oceans. However, a number of processes could potentially contribute. These may include adiabatic lofting, cloud-top radiative cooling, Kelvin waves forced by transient deep convection (Randel and Wu, 2005), quasi-horizontal eddies, and convective overshooting followed by turbulent mixing (Danielsen 1993). They are difficult to separate based on a simple comparison between sequences of profiles during a succession of high and low convective periods. Since the major difference between land and oceanic convection is the large diurnal variation of the first compared to the second, better insight on the relative contributions of the above processes may be gained by looking at the diurnal cycle of temperature.

\section{Diurnal temperature change in the TTL and echo top height associated to convection}

The study makes use of the series of the four daily ascents at 00:00, 06:00, 12:00 and 18:00 UT available between 5 and 21 February. Since it takes about one hour for the balloon to reach the tropopause, the measurements in the TTL were performed

approximately at 22:00, 04:00, 10:00 and 16:00 LT. Figure 3 shows the diurnal change of temperature compared to the morning ascent at 10:00 LT during the periods of high ( 5 days from 5-9 February), medium (8 days from 14-21 February) and low convection (4 days from 10-13 February).

Systematic and significant diurnal changes could be seen during the three periods:

- the daytime warming and nighttime cooling of the surface layer of increasing amplitude at decreasing convection and thus cloudiness;
ACPD

7, 8933-8950, 2007

Is there a

stratospheric

fountain?

J.-P. Pommereau and

G. Held

Title Page

Abstract

Conclusions

Tables

Figures

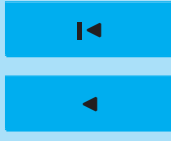

- I

Back

Close
Full Screen / Esc

Printer-friendly Version

Interactive Discussion 
- the warming of the troposphere by $1^{\circ} \mathrm{C}$ in the afternoon and the evening between 5 and $12 \mathrm{~km}$ amplifying with convection intensity;

- the cooling of the TTL between 16 and $19 \mathrm{~km}$ in the afternoon also amplifying with convective activity $\left(-1.6^{\circ} \mathrm{C}\right.$ medium, $-3.4^{\circ} \mathrm{C}$ high);

- the slight warming of $1-2^{\circ} \mathrm{C}$ of the lower stratosphere in the afternoon and the evening.

As indicated by the absence of difference between daytime (10:00 and 16:00 LT) and nighttime (22:00 and 04:00 LT) temperature between 3 and $17 \mathrm{~km}$ during the cloud-free period, there is no significant bias related to the solar heating of the sensor corrected using the radiosondes manufacturer's procedure. The only experimental limitation is the absence of temperature readings above $21-22 \mathrm{~km}$ during the highly convective period because of the lower altitude of the burst of the balloon after crossing thick cumulonimbus clouds.

The observed diurnal temperature changes associated to convection are in the same direction of the difference between convective and low-convective periods, but displays also significant differences. At all levels, the largest change occurs during the development phase of convection in the afternoon. On top of the large daytime heating of the surface, the troposphere warms, but by $1^{\circ} \mathrm{C}$ only and to higher altitude very near the LRT. However, the diurnal cycle contributes to only one fifth of the heating observed between convective and low-convective days, suggesting that most of the difference is due to advection of warm and wet air at synoptic scale. Since the daytime warming of the troposphere is due to the heat released by water vapour condensation exceeding the cooling of ascending air parcels, the higher altitude of the top heated layer suggests the presence of high humidity at higher altitude $(15 \mathrm{~km}$ in high convection, $13 \mathrm{~km}$

The average amplitude of the afternoon cooling of the TTL represents half of the mean cooling associated to convection compared to the low-convective period. During the five most active days it varies from $-2^{\circ} \mathrm{C}$ to $-9^{\circ} \mathrm{C}$. But it starts at the LRT only,

Is there a

stratospheric fountain?

J.-P. Pommereau and G. Held

Title Page

Abstract Introduction

Conclusions

Tables References Figures

14

4

Back

Close

Full Screen / Esc

Printer-friendly Version

Interactive Discussion 
reaching a maximum at $17 \mathrm{~km}$ at the altitude of the CPT instead of the LRT. It has no impact on the altitude of the CPT, which remains constant between 10:00 and 16:00 LT, which would be the case if adiabatic lofting were involved. Later in the evening, the amplitude and altitude of the cooling first drop between 16:00 and 22:00 LT and then 5 stabilize during the night when convection collapses. However, the warming of $2^{\circ} \mathrm{C}$ above $17 \mathrm{~km}$ is far smaller than the $15^{\circ} \mathrm{C}$ which could be expected from an adiabatic descent of $1.5 \mathrm{~km}$, implying mixing instead. Since the daytime radiative effect at these levels is heating due to solar light absorption by ozone, e.g. Gettelman et al. (2004), or eventually cloud-top (Sherwood et al., 2003), the potential effect of radiation during 10 daytime could be only the masking of part of the cooling. In the opposite direction, the potential of radiative processes in the TTL during nighttime would be cooling and not warming. Since winds between 16 and $20 \mathrm{~km}$ remained very light $(<5 \mathrm{~m} / \mathrm{s}$ from E-SE) during the whole campaign, neither large scale eddies or waves could be responsible for systematic changes within 6-h. The possible contribution of gravity waves was 15 investigated by looking at the deviation of temperature compared to smoothed profiles. The average RMS amplitude of temperature fluctuations of vertical wavelength shorter than $2 \mathrm{~km}$ was found to increase from $0.3^{\circ} \mathrm{C}$ in the troposphere to $0.7^{\circ} \mathrm{C}$ above the LRT, but not showing any diurnal change. The contribution of gravity waves to the afternoon cooling is thus insignificant. Finally, since the absence of change in the CPT altitude during the cooling phase and the evening partial heating are incompatible with an adiabatic process, the only remaining explanation of the cooling event in the TTL is the insertion of cold air by overshooting turrets followed by mixing with warmer stratospheric air, as suggested by Danielsen $(1982,1993)$.

Note that a diurnal signal also appears at higher altitude in the stratosphere during 25 medium and low-convective days, exhibiting a daytime heating by $1-2^{\circ} \mathrm{C}$ at $22-25 \mathrm{~km}$, shifting downwards to $20-22 \mathrm{~km}$ in the late afternoon and the evening, followed by a nighttime cooling. Unfortunately, there is no data available at those altitudes above high convection. Within the dispersion of the measurements, the picture is consistent with a diurnal cycle of the order of $1^{\circ} \mathrm{C}$ amplitude as expected from the daytime heating by

\section{Is there a \\ stratospheric fountain?}

J.-P. Pommereau and G. Held

Title Page
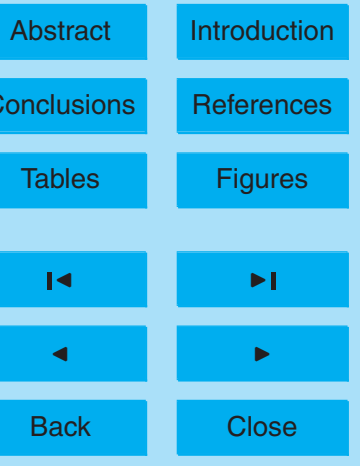

Full Screen / Esc

Printer-friendly Version

Interactive Discussion 
solar light absorption in the shortwave, followed by the nighttime cooling by long-wave emission (e.g., Gettelman et al., 2004).

Finally, the timing and the altitude of the TTL cooling are very consistent with the diurnal change of echo top heights extracted from the TITAN statistics (Dixon and

5 Weiner, 1993) of the Bauru radar observations within its $240 \mathrm{~km}$ range (TITAN settings: $10 \mathrm{dBz}$ reflectivity threshold, storm volume $\geq 50 \mathrm{~km}^{3}$, minimum lifetime of cell $15 \mathrm{~min}$ ), displayed in Fig. 4. Every cell complying with these criteria yielded "one count" per volume scan (every $7.5 \mathrm{~min}$ ). After minimum activity at 09:00-10:00 LT convective clouds start developing at around 11:00 LT, reaching a maximum average altitude of 18.3 and $1014.9 \mathrm{~km}$, respectively on high and medium convective days around 14:00 LT, before decreasing slowly in the late afternoon and collapsing at night. But on most active days, the echo tops reach even higher altitudes of 19.6 and $18.1 \mathrm{~km}$, respectively, during the early afternoon, very consistent with those of the top levels of the cooling reported by the radiosondes at 16:00 LT. Interestingly, and although no echoes are reported in 15 the morning during low-convective days on 10-13 February, radar observations show that convection also develops in the afternoon, suggesting a possible contribution of overshooting on the TTL temperature even on those days.

\section{Summary and discussion}

The above analysis provides an experimental evidence of the existence of a mixing 20 layer and of the strong influence of convection on the thermal structure of the TTL up to $450 \mathrm{~K}$ in the lower stratosphere, as suggested by Danielsen $(1982,1993)$ and Sherwood (2000). The strong overshooting is shown associated with the fast diurnal development phase of convection over land in the early afternoon. Although the injection of cold air explains partly only the cooling of the TTL associated with convection to which, radiation, adiabatic lofting and Rossby and Kelvin waves may also contribute, the afternoon overshoot and turbulent mixing is the only process that allows irreversible vertical transport in the stratosphere. As suggested by cloud resolving model (CRM)

Is there a

stratospheric fountain?

J.-P. Pommereau and G. Held

Title Page

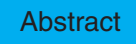

Introduction

Conclusions

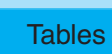

References

Tables

Figures

14

4

Back

Close

Full Screen / Esc

Printer-friendly Version

Interactive Discussion 
simulations (Chaboureau et al., 2007, Grovesnor et al., 2007) it could provide an explanation for the presence of ice particles and hydrated layers in largely sub-saturated air $2 \mathrm{~km}$ above the tropopause at $18-19 \mathrm{~km}(410-430 \mathrm{~K})$ reported by the HIBISCUS balloons (Nielsen et al., 2007, Durry et al., 2007) and the TROCCINOX high altitude

5 Geophysica aircraft (Chaboureau et al 2007) over the Bauru area. It could also provide an explanation for the maximum concentration of tropospheric chemical substances in the TTL above continents as seen by the ODIN, MLS, HALOE and MOPITT, $\mathrm{N}_{2} \mathrm{O}, \mathrm{CH}_{4}$ and CO measurements (Ricaud et al., 2007).

Little experimental information exists in the literature regarding the possible impact 10 of convection on the thermal structure of the TTL, difficult to observe from space and particularly from sun-synchronous missions. Although it is not surprising that a diurnal cycle was not observed with AIRS aboard AURA limited to oceanic areas (Kim and Dessler, 2004), it is unlikely that two profiles per day would be enough to see it, even over land. The only reference found to a diurnal signature of convection on the thermal 15 structure of the TTL, is the observation from four daily radiosonde ascents during a 3-day convective period off the coast of the large island of Borneo, indicating a cooling of $6-10^{\circ} \mathrm{C}$ at $18 \mathrm{~km}$ in the afternoon around $14: 00 \mathrm{LT}$ during the first two days, lasting until 20:00 LT on the third day (Johnson and Kriete, 1982).

Overall, injection of cold air by irreversible mixing of convective overshoots as pro20 posed by Danielsen (1982) do not appear as episodic isolated features, but common and systematic events over a land convective area, defining a Stratospheric Fountain. Though the two-stages process proposed by Sherwood (2000) may also be operative, it offers a mechanism for producing the chemical, moisture and thermal properties observed in the stratosphere. However, the still open question is to know the relative contribution of the two processes and whether the Stratospheric Fountain is operative also in Africa and Indonesia. The even higher frequency of TRMM OPF and LIS lightning events over Africa, South-East Asia, the Indonesian Islands and Northern Australia depending on the season (Liu and Zipzer, 2005), suggest the presence of several "Stratospheric Fountains" over continents in contrast to the oceanic area of Mi-

Is there a

stratospheric fountain?

J.-P. Pommereau and G. Held

Title Page

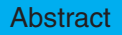

Conclusions

Tables

Figures

14

4

Back

Introduction
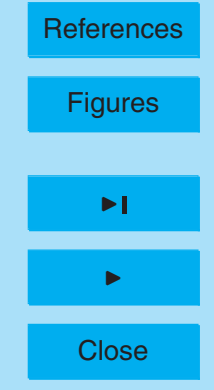

Full Screen / Esc

Printer-friendly Version

Interactive Discussion 
Acknowledgements. We thank the personnel of the Meteorological Research Institute (IPMet) of the São Paulo State University (UNESP) and the students of the Federal University of Rio 5 de Janeiro for preparing the radiosondes and operating the radar. The National Center for Atmospheric Research (NCAR) in Boulder, Co, USA, is gratefully acknowledged for the TITAN Software and its adaptation for IPMet's radars as part of a collaborative project. This study was supported by the European Commission (HIBISCUS contract EVK2-2001-000111), CNRS in France, and FASESP (project TROCCIBRAS) in Brazil.

\section{References}

Alcala, C. M. and Dessler, A. E : Observations of deep convection in the tropics using the Tropical Rainfall Measuring Mission (TRMM) precipitation radar, J. Geophys. Res., 107, 4792, doi:10.1029/2002/D002457, 2002

Chaboureau, J.-P., Cammas, J.-P. Duron, J., Mascart, P. J., Sitnikov, N. M., and Voessing, H.-J.: A numerical study of cross-tropopause transport by convective overshoots during the Troccinox golden day, Atmos. Chem. Phys., 7, 1731-1740, 2007, http://www.atmos-chem-phys.net/7/1731/2007/.

Corti, T., Luo, B. P., and Peter, T.: Mean radiative energy balance and vertical mass fluxes in the equatorial upper troposphere and lower stratosphere, Geophys. Res. Lett., 32, L06802, doi:10.1029/2004GL021889, 2005.

Corti, T., Luo, B. P. , Fu, Q., Vömel, H., and Peter, T.: The impact of cirrus clouds on tropical troposphere-to stratosphere transport, Atmos. Chem. Phys. Discuss, 6, 1725-1747, 2006.

Danielsen, E. F.: A dehydration mechanism for the stratosphere, Geophys. Res. Lett., 9, 605608, 1982.

25 Danielsen, E. F.: In situ evidence of rapid, vertical, irreversible transport of lower tropospheric air into the lower stratosphere by convective cloud turrets and by large scale up welling in tropical cyclones, J. Geophys. Res, 98, 8665-8681, 1993.

Dessler, A. E.: The effect of deep, tropical convection on the tropical tropopause layer, J. Geophys. Res., 107, 4033, doi:10.1029/2001JD000511, 2002.

\section{Is there a \\ stratospheric fountain?}

J.-P. Pommereau and

G. Held

\section{Title Page}

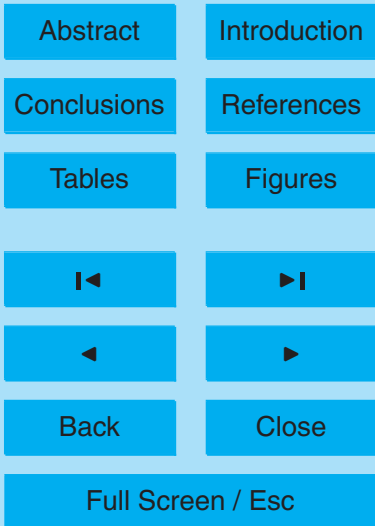

Printer-friendly Version

Interactive Discussion 
Dixon, M. and Weiner, G.: TITAN: Thuderstorm idenetification, tracking, analysis and nowcasting - a radar-based methodology, J. Atmos. Ocean. Technol., 10, 785-797, 1993

Durry, G., Huret, N., and Hauchecorne, A.: Isentropic advection and convective lifting of water vapor in the UT - LS as observed over Brazil $\left(22^{\circ} \mathrm{S}\right)$ in February 2004 by in situ high5 resolution measurements of $\mathrm{H}_{2} \mathrm{O}, \mathrm{CH}_{4}, \mathrm{O}_{3}$ and temperature, Atmos. Chem. Phys. Discuss, 6, 12469-12501, 2006.

Folkins, I., Loewenstein, M., Podolske, J., Oltmans, S. J., and Profitt, M.: A barrier to vertical mixing at $14 \mathrm{~km}$ in the tropics: Evidence from ozonesondes and aircraft measurements, $\mathrm{J}$. Geophys. Res., 104, 22 095-22 102, 1999.

10 Folkins, I., Braun, C., Thompson, A. M., and Whitte, J.: Tropical ozone as an indicator of deep convection, J. Geophys. Res., 107, 4184, doi:10.129/2001JD001178, 2002.

Gettelman, A., Salby M. L., and Sassi, F: The distribution and influence of convection in the tropical tropopause region, J. Geophys. Res., 107, 4080, doi:10.1029/2001JD001048, 2002

Gettelman, A., de F. Forster, P. M., Fujiwara, M., Fiu, Q., Vömel, H., Gohar, L. K., Johanson C., 15 and Ammerman, M.: Radiation balance of the tropical layer, J. Geophys. Res. 109, D07103, doi:10.1029/2003JD004190, 2004.

Grosvenor D. P., Choularton, T., Coe, H., and Held, G.: Cloud Resolving Model simulations of dehydration by deep convection of the TTL and lower stratosphere, Atmos. Chem. Phys. Discuss., 7, 7277-7346, 2007,

20 http://www.atmos-chem-phys-discuss.net/7/7277/2007/.

Hartmann, D. L., Holton, J. R., and Fu, Q.: The heat balance of the tropical tropopause, Q. J. R. Meteorol. Soc., 124, 1579-1604, 2001.

Highwood, E. J. and Hoskins, B. J.: The tropical tropopause, Q. J. R. Meteorol. Soc., 124, 1579-1604, 1998.

Holton, J. R. and Gettelman, A.: Horizontal transport and the dehydration of the stratosphere, Geophys. Res. Lett., 14, 2799-2802, 2001.

Johnson, R. H. and Kriete, D. C.: Thermodynamic and circulation characteristics of winter monsoon tropical mesoscale convection, Month. Weather Rev., 10, 1898-1911, 1982.

$\mathrm{Kim}, \mathrm{H}$. and Dessler, A. E.: Observations of convective cooling in the tropical tropopause layer in AIRS data, Atmos. Chem. Phys. Discuss, 4, 7615-7629, 2004.

Kuang, Z. and Bretherton, C. S.: Convective influence on the heat balance of the tropical tropopause layer: a cloud-resolving model study, J. Atm. Science, 2919-2927, 2004.

Liu, C. and Zipser, E. J.: Global distribution of convection penetrating the tropical tropopause,

\section{Is there a \\ stratospheric \\ fountain?}

J.-P. Pommereau and

G. Held

\section{Title Page}

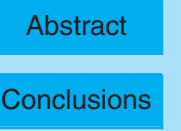

Tables

Figures

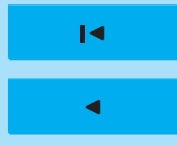

$\rightarrow 1$

Back

Close

Full Screen / Esc

Printer-friendly Version

Interactive Discussion 
J. Geophys. Res., D23104, doi:10.1029/2005JD006063, 2005.

Newell, R. E. and Gould-Stewart, S.: A stratospheric fountain?, J. Atmos. Science, 38, 27892796, 1981.

Nielsen, J. K., Larsen, N., Cairo, F., Di Donfrancesco, G., Rosen, J. M., Durry, G., Held, G., and 5 Pommereau, J.-P.: Solid particles in the tropical lower stratosphere, Atmos. Chem. Phys., 7, 685-695, 2007,

http://www.atmos-chem-phys.net/7/685/2007/.

Nowicki, S. M. J. and Merchant, C. J.: Observations of the diurnal and spatial variability of radiative forcing by equatorial deep convective clouds, J. Geophys. Res., 109, D11202, 10 doi:10,1029/2003D004176, 2004.

Pommereau, J.-P., Garnier, A., Held, G., et al.: An overview of the HIBISCUS campaign, Atmos. Chem. Phys. Discuss., 7, 2389-2475, 2007, http://www.atmos-chem-phys-discuss.net/7/2389/2007/.

Randel, W. J. and Wu, F.: Kelvin wave variability near the equatorial tropopause ob15 served in GPS radio occultation measurements, J. Geophys. Res., 110, D03102, doi:10.1029/2004JD005006, 2005.

Ricaud, P., Barret, B., Attié, J.-L., et al.: Impact of land convection on troposphere-stratosphere exchange in the tropics, Atmos. Chem. Phys. Discuss., 7, 3269-3300, 2007, http://www.atmos-chem-phys-discuss.net/7/3269/2007/.

Sherwood, S. C.: A Stratospheric "Drain" over the Maritime continent, Geophys. Res. Lett., 27, 677-680, 2000.

Sherwood, S.C., and Dessler, A.E.: On the control of stratospheric humidity, Geophys. Res. Lett., 2513-2516, 2000

Sherwood, S. C., Horinouchi, T., and Zeleznik, H. A.: Convective impact on temperatures observed near the tropical tropopause, J. Atmos. Science, 60, 1847-1856, 2003.

Sherwood, S. C. and Dessler, A. E.: Convective mixing near the tropical tropopause: Insights from seasonal variations, J. Atmos. Sci., 60, 2674-2685, 2003.

Seidel, D. J., Ross, R. J., and Angell, J. K.: Climatological characteristics of the tropical tropopause as revealed by radiosondes, J. Geophys. Res., 106, 7857-7878, 2001.

30 Thuburn, J. and Craig, G. C.: On the temperature structure of the tropical sub stratosphere, J. Geophys. Res., 107, 4017, doi:10.1029/2001JD000449, 2002.

Yang, G. Y. and Slingo, J.: The diurnal cycle in the tropics, Month. Weather. Rev., 129, 784-801, 2001.

\section{Is there a \\ stratospheric fountain?}

J.-P. Pommereau and

G. Held

\section{Title Page}

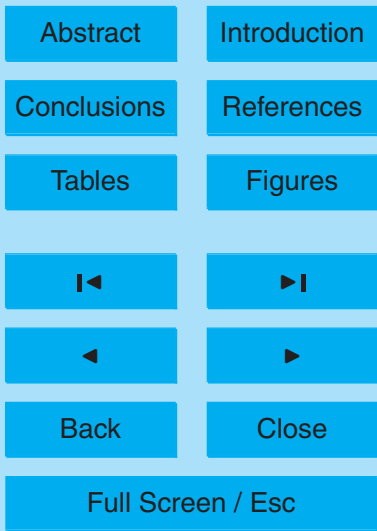

Printer-friendly Version

Interactive Discussion 


\section{ACPD}

$7,8933-8950,2007$

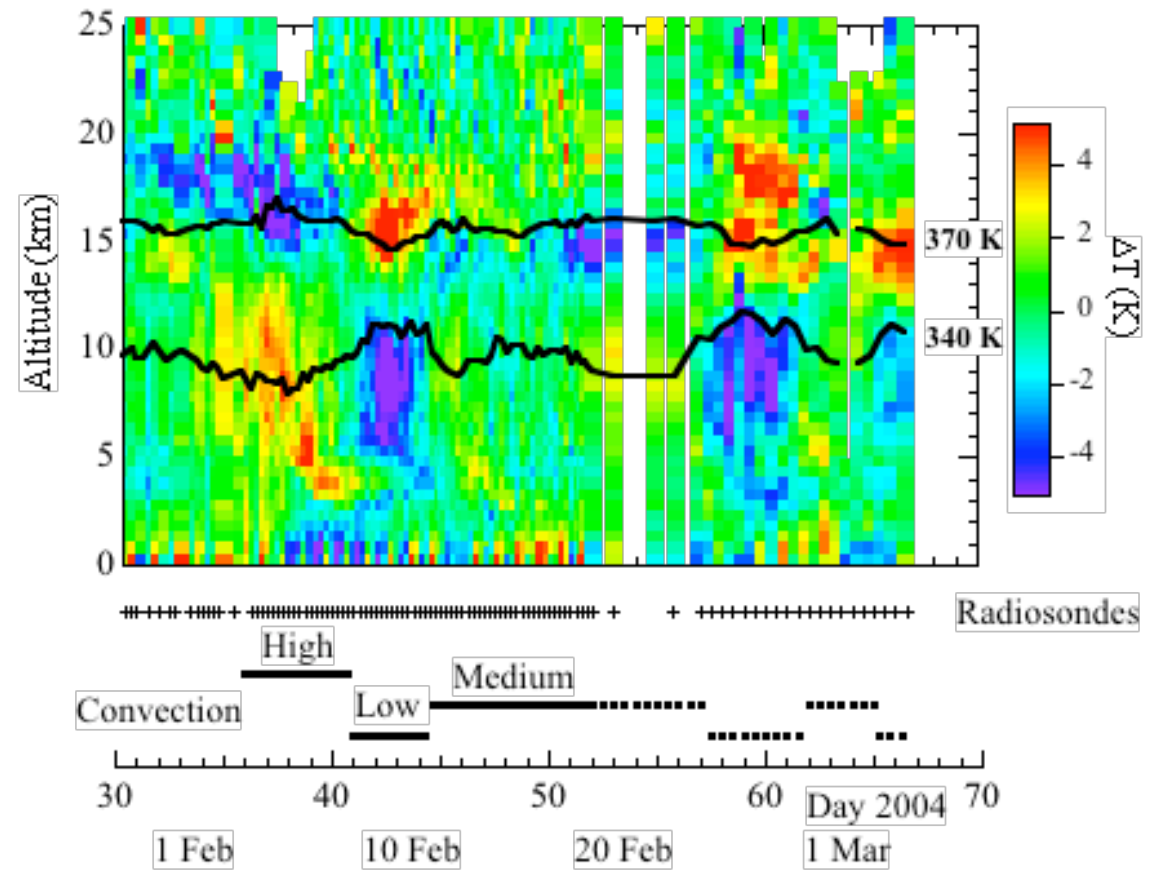

Fig. 1. Temperature deviation compared to mean campaign profile and dates of radiosonde ascents. The difference in altitude between the $370 \mathrm{~K}$ and $340 \mathrm{~K}$ levels is an indicator of convection intensity.

\section{Is there a stratospheric fountain?}

J.-P. Pommereau and G. Held

Title Page

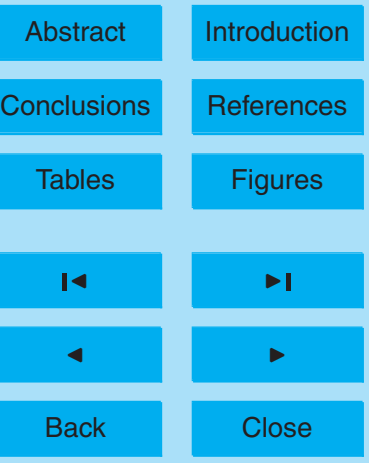

Full Screen / Esc

Printer-friendly Version

Interactive Discussion 


\section{ACPD}

7, 8933-8950, 2007
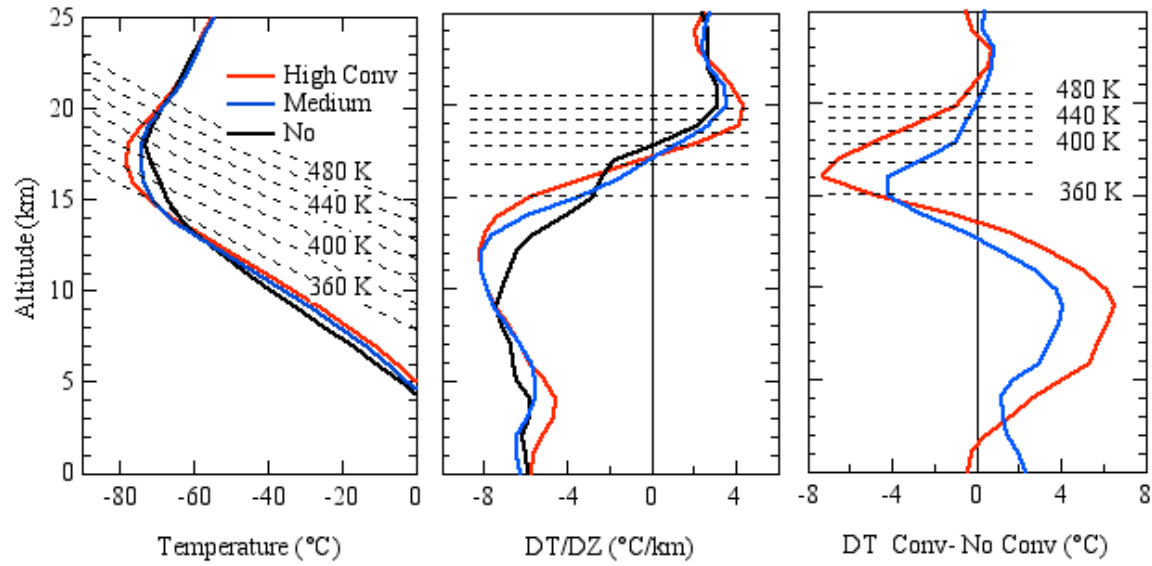

\section{Is there a stratospheric fountain?}

J.-P. Pommereau and G. Held

Title Page

Abstract

Conclusions

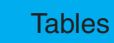

14

4

Back
Introduction

References

Figures

$>1$

Fig. 2. Average temperature (left) and lapse rate (middle) during high, medium and nonconvective periods and difference between convective and non-convective profiles (right).

\section{Full Screen / Esc}

Printer-friendly Version 


\section{ACPD}

7, 8933-8950, 2007

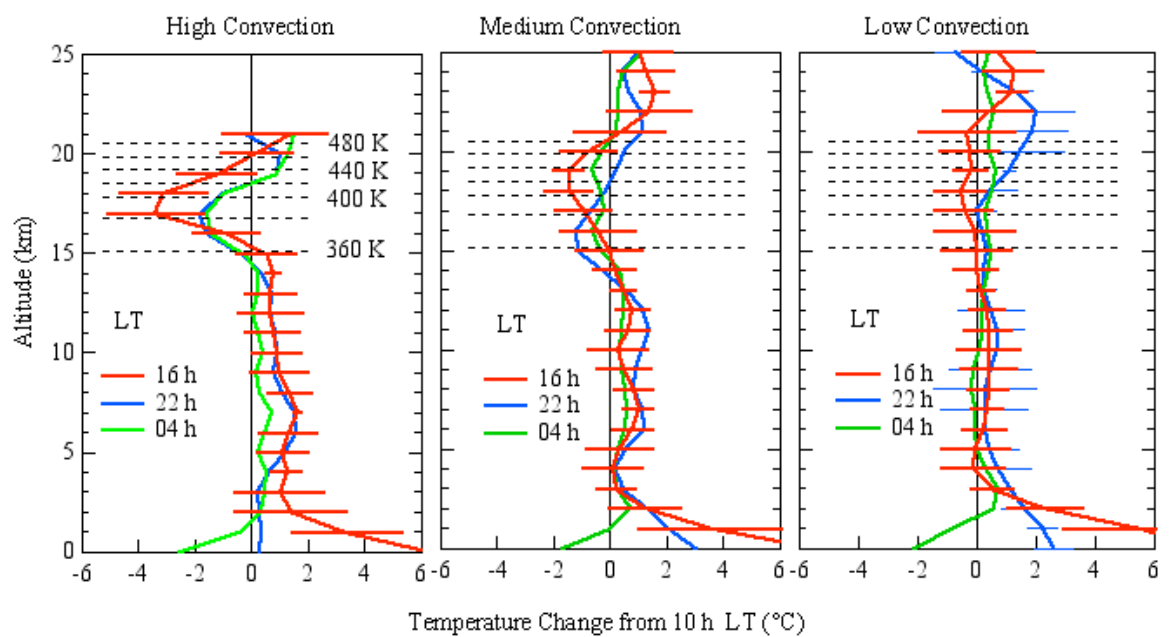

\section{Is there a \\ stratospheric \\ fountain?}

J.-P. Pommereau and

G. Held

Title Page

Abstract

Introduction

Conclusions

References

Tables

Figures

14

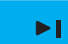

Fig. 3. Diurnal change of temperature compared to morning profile at 10:00 LT during high, medium and low convection periods. Error bars on most relevant profiles show standard deviations. Note the increase RMS in the TTL during the high convective period suspected to be related to the distance between the radiosonde and the cloud turrets.

4

Back

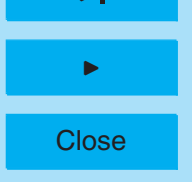

Full Screen / Esc

Printer-friendly Version

Interactive Discussion 


\section{ACPD}

\section{7, 8933-8950, 2007}

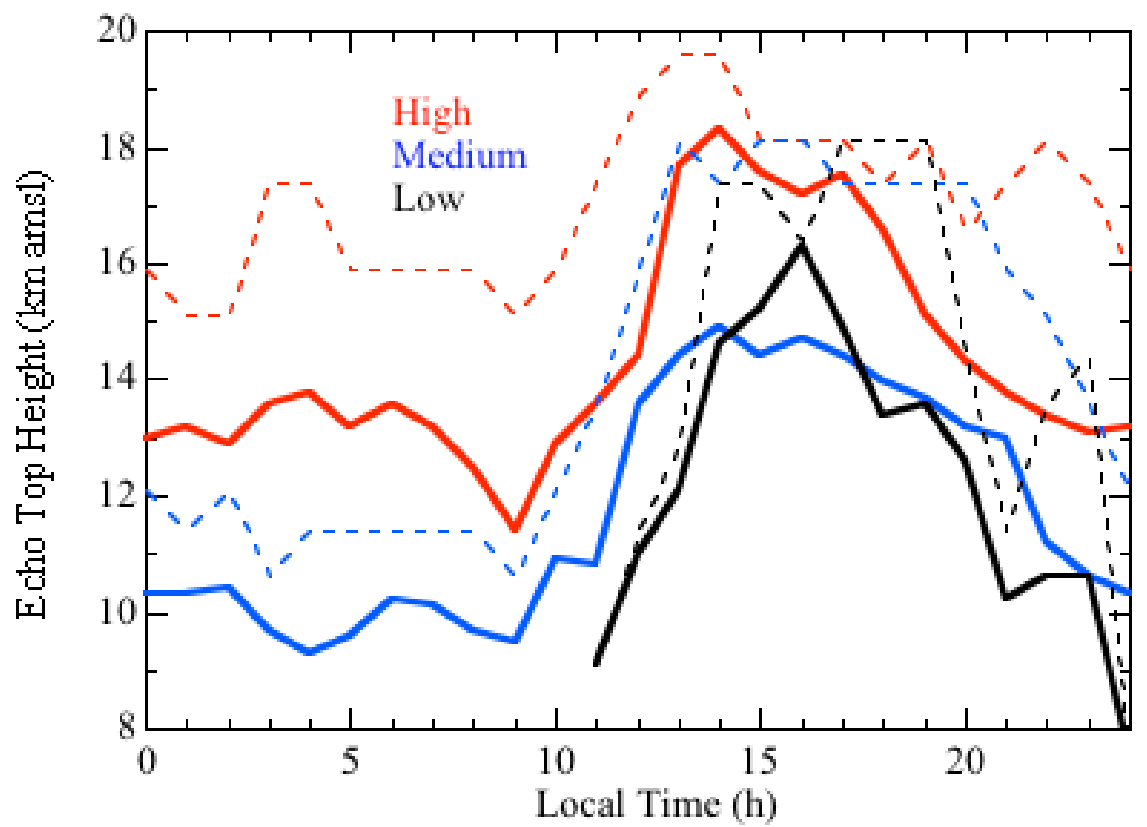

\section{Is there a stratospheric fountain?}

J.-P. Pommereau and G. Held

Title Page

Abstract

Conclusions

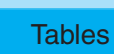

14

4

Back

Full Screen / Esc

Printer-friendly Version

\section{Close}

Fig. 4. Diurnal variation of mean (solid) and maximum (dotted) cloud-top height seen by the radar within its $240 \mathrm{~km}$ range during the high (3719 counts/day average), medium (2293 counts/day) and low (873 counts/day) convective periods.

\section{Introduction}

References

Figures

$\rightarrow$

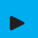

Interactive Discussion 